\title{
UPAYA PENINGKATAN KESEHATAN KLIEN HIPERTENSI di KLINIK MERCUBAKTIJAYA
}

\section{Aida Minropa ${ }^{1}$, Nurleny², Dewi Susillawati ${ }^{3}$, Nila Eza Fitria ${ }^{4}$, Leni Sastra ${ }^{5}$, Citra Werdi Edo $^{6}$, Anita Revanda ${ }^{7}$}

1 Prodi S1 Keperawatan / STIKes MERCUBAKTIJAYA Padang

${ }^{2}$ Prodi D III Keperawatan / STIKes MERCUBAKTIJAYA Padang

3Prodi S1 Kebidanan / STIKes MERCUBAKTIJAYA Padang

4 Prodi D III Kebidanan / STIKes MERCUBAKTIJAYA Padang

E-mail korespondensi: aidaminropa1@gmail.com

\section{Article History: \\ Received: 07 April 2021 \\ Revised: 18 April 2021 \\ Accepted: 13 Oktober 2021}

Kata Kunci : Hipertensi, Senam Hipertensi, Pengobatan Herbal

\begin{abstract}
Abstrak:
Latar Belakang: Hipertensi adalah salah satu penyakit kronis yang jika tidak ditangani akan menyebabkan penyakit lain dan mengancam nyawa. Klinik MERCUBAKTIJAYA melayani pasien dengan penyakit kronis termasuk penyakit hipertensi yang akan diberikan pelayanan Prolanis. Catatan kunjungan pasien yang berobat di klinik MERCUBAKTIJAYA pada bulan Desember 2020 kasus hipertensi 8 orang. Pasien ini datang secara berkala ke klinik untuk memeriksakan kesehatannya oleh karena itu perlu dibuatkan wadahnya dengan tujuan adanya kegiatan yang dapat mengontrol tekanan darah dan meningkatkan derajat kesehatan pasien. Berdasarkan data diatas kami melaksanakan kegiatan Upaya Peningkatan Kesehatan Pasien Hipertensi melalui senam hipertensi dan pengobatan herbal sekaligus membentuk wadah untuk pasien penyakit hipertensi.
\end{abstract}

Metode: Kegiatan pengabdian kepada masyarakat ini dilakukan di Klinik MERCUBAKTIJAYA Padang pada pasien hipertensi hari Sabtu tanggal 16 Januari 2021. Kegiatan ini diawali dengan pengukuruan tekanan darah, melakukan penyuluhan kesehatan serta simulasi senam hipertensi dan diakhiri dengan pengukuran tekanan darah.

Hasil: Kegiatan pengabdian ini dihadiri oleh 6 peserta. Klien yang hadir pada kegiatan berperan aktif selama kegiatan berlangsung, klien mengajukan pertanyaan saat sesi diskusi setelah penyuluhan dan mengikuti semua gerakan senam yang di ajarkan. Pada saat ini juga dibentuk wadah Prolanis Hipertensi. 
Keywords: Hypertension, Hypertension Gymnastics, Herbal Medicine

\begin{abstract}
:
Background: Hypertension is a chronic disease which, if not handled, will cause other and life-threatening diseases. MERCUBAKTIJAYA Clinic is one of the premiere clinics that serves patients with chronic diseases including hypertension who will be given Prolanis services. In accordance with the records of patient visits at the MERCUBAKTIJYA clinic in December 2020, as many as 8 people experienced hypertension. These patients will come regularly to the clinic to have their health checked and get treatment, therefore it is necessary to make a container with the aim of activities that can control blood pressure and improve the patient's health status. Based on the data above, we carry out efforts to improve the health of hypertension patients through hypertension exercise and herbal medicine as well as forming a forum for patients with hypertension.

Methods: This community service activity was carried out at the MERCUBAKTIJYA Padang Clinic for patients who were registered as hypertension sufferers on Saturday, January 16, 2021. This activity began with measuring blood pressure and conducting health education about Hypertension and Herbal Medicine as well as a hypertension exercise simulation and ended with back blood pressure measurement. Those who experience health complaints are not allowed to do gymnastics.

Result: This service activity was attended by 6 target participants. When measuring blood pressure, all clients were found to have hypertension. Clients who attend the activity play an active role during the activity, this can be seen from the clients asking questions during the discussion session after counseling and following all the gymnastics movements that are taught. At this time also directly in the form of the Hypertension Prolanis container.
\end{abstract}

\title{
Pendahuluan
}

Status kesehatan masyarakat dapat ditingkatkan dengan jaminan sosial bidang kesehatan, sesuai dengan Peraturan Presiden Nomor 19 Tahun 2016 tentang Jaminan Kesehatan Pasal 21 Ayat 1, salah satu manfaat yang didapatkan oleh peserta Badan Penyelenggaraan Jaminan Sosial (BPJS) Kesehatan yaitu pelayanan kesehatan promotif dan preventif, salah satunya ialah Prolanis. Program dengan model pengelolaan penyakit kronis bagi peserta penderita penyakit kronis yang disebut sebagai "PROLANIS" atau "Program Pengelolaan Penyakit Kronis" (Bustan, 2015). Prolanis tersebut menggunakan pendekatan proaktif yang melibatkan peserta, fasilitas kesehatan, dan BPJS kesehatan dengan tujuan mencegah timbulnya komplikasi berkelanjutan khususnya penyakit Hipertensi dan DM tipe 2. Kegiatan Prolanis ini mencakup upaya-upaya pencegahan komplikasi berlanjut dan peningkatan kesehatan masyarakat, yaitu meliputi kegiatan konsultasi medis, klub prolanis, home-visit, dan skrining kesehatan. Penyakit kronis merupakan masalah kesehatan yang berkaitan 


\section{Jurnal ABDI MERCUSUAR}

Vol. 01, No. 02, Desember, 2021, pp. 001- 006

dengan gejala-gejala yang membutuhkan penatalaksanaan jangka panjang, serta merupakan masalah kesehatan yang serius dan menyebabkan kematian terbesar di dunia (Kusniadi \& Nurahmani, 2014)

Berdasarkan data World Health Organization (WHO) prevalensi penyakit kronis di dunia mencapai 70\% dari kasus yang mengakibatkan kematian, 80\% diantaranya di sebabkan oleh penyakit jantung termasuk hipertensi. Data Riset Kesehatan Dasar (Riskesdas) tahun 2013 penyakit kronis merupakan salah satu penyebab utama kematian di Indonesia. Penyakit kronis ini meliputi Asma, Penyakit Paru Obstruksi Kronis (PPOK), kanker, Diabetes Melitus (DM), Hipertiroid, Hipertensi, Jantung Koroner, Gagal Jantung, Stroke, Gagal Ginjal Kronis, Batu Ginjal, Penyakit sendi atau Rematik. Prevalensi penderita hipertensi di Indonesia pada tahun 2013 untuk umur $\geq 18$ tahun sebesar 25,8\% kejadian ini telah menurun dari survei Riskesdas tahun 2007 yaitu sebesar $31,7 \%$.

Proporsi hipertensi di Provinsi Sumatera Barat tahun 2017 sebesar 952.956 kasus terdiri dari 382.069 kasus baru dan 570.887 kasus lama. Prevalensi hipertensi di Kota Padang menurut survei Riskesdas tahun 2013 pada umur $\geq 18$ tahun sebesar 24,2\%. Menurut Dinas Kesehatan Kota Padang pada tahun 2016 hipertensi termasuk sepuluh penyakit terbanyak yang berkembang di Kota Padang dengan urutan kedua setelah ISPA dengan jumlah 47.902 kasus. pada tahun 2017 menjadi 18.973 kasus.

Klinik MERCUBAKTIJAYA adalah salah klinik pratama yang melayani pasien dengan BPJS pada semua penyakit termasuk dengan penyakit Kronis. Pasien dengan penyakit kronis datang berobat secara berkala ke klinik dan akan diberikan pelayanan Prolanis. Sesuai dengan catatan kunjungan pasien yang berobat di klinik MERCUBAKTIJYA pada bulan Desember 2020 yang mengalami penyakit DM sebanyak 8 orang dan penyakit Hipertensi sebanyak 8 orang. Pasien ini akan datang secara berkala ke klinik untuk memeriksakan kesehatannnya dan mendapat pengobatan. Khusus Pasien penyakit kronis Diabetes Melitus sudah dibentuk wadahnya jika datang berobat ke klinik, sementara untuk pasien dengan penyakit Kronis Hipertensi belum ada wadahnya ini belum ada. Oleh karena itu kami tertarik untuk membuat wadah sekaligus memberikan kegiatan penyuluhan kesehatan pada pasien tersebut.

Beraktivitas dengan senam secara teratur juga membantu lansia merupakan cara lain untuk mengontrol tekanan darah dan mengkonsumsi obat herbal juga obat tekanan darah (Lumempouw et al., 2016). Berdasarkan permasalahan yang tejadi pada pasien di atas itulah maka perlu dilakukan upaya peningkatan pada klien hipertensi melalui Senam Hipertensi dan Pengobatan Herbal. Diharapkan dengan adanya informasi yang diberikan, pasien mengerti tentang penyakit hipertensi sehingga dapat mengurangi timbulnya penyakit hipertensi serta dapat mencegah meningkatnya angka kesakitan dari penderita hipertensi khususnya pada pasien hipertensi Klinik MERCUBAKTIJAYA.

\section{Metode Pelaksanaan}

Tahap persiapan yang dilakukan pada kegiatan ini adalah dengan melakukan koordinasi dengan TIM Pengabdian Kepada Masyarakat untuk mempersiapkan kebutuhan selama kegiatan, melakukan koordinasi dengan pimpinan Klinik 


\section{Jurnal ABDI MERCUSUAR}

MERCUBAKTIJAYA terkait sasaran dan kapan waktu pelaksanaan.

Kegiatan Pengabdian Kepada Masyarakat ini dilakukan pada tanggal 16 Januari 2021 di Klinik MERCUBAKTIJYA Padang pada pasien yang tercatat sebagai penderita Hipertensi yang berjumlah 8 orang. Tahap Kegiatan ini diawali dengan pasien registrasi, pengukuran langsung dilakukan pengukuran tekanan darah. Selanjutnya dilakukan penyuluhan kesehatan tentang Hipertensi dan Pengobatan Herbal serta simulasi senam hipertensi dan diakhiri dengan pengukuran tekanan darah kembali, yang mengalami keluhan kesehatan tidak di perbolehkan melakukan senam.

\section{Hasil}

Kegiatan pengabdian ini dihadiri oleh 6 peserta yang menjadi sasaran. Saat pengukuran tekanan darah semua klien ditemukan mengalami hipertensi.

Tabel 1. Hasil Pengukuran Tekanan Darah Pasien Prolanis di Klinik MERCUBAKTIJAYA

\begin{tabular}{ccccc}
\hline \multirow{2}{*}{ No } & \multirow{2}{*}{ Nama } & \multirow{2}{*}{ Alamat } & \multicolumn{2}{c}{ Hasil tekanan darah (Mmhg) } \\
\cline { 3 - 4 } & & \multirow{2}{*}{ Ket } \\
\hline 1 & Ny. M & Pondok Kopi & $150 / 110$ & $150 / 110$ \\
\hline 2 & Ny. Y & Pondok Kopi & $165 / 104$ & $165 / 104$ \\
\hline 3 & Tn, D & Kuranji & $140 / 95$ & $155 / 95$ \\
\hline 4 & Tn A & Pondok Kopi & $157 / 95$ & $156 / 95$ \\
\hline 5 & Ny. E & Siteba & $160 / 100$ & $160 / 100$ \\
\hline 6 & Tn J & Siteba & $160 / 100$ & $160 / 100$ \\
\hline 7 & Ny. M & Siteba & $160 / 80$ & $165 / 80$ \\
\hline 8 & Tn.S & Siteba & $160 / 70$ & $160 / 70$ \\
\hline
\end{tabular}

Klien yang hadir pada kegiatan berperan aktif selama kegiatan berlangsung, hal ini dapat dilihat dari klien mengajukan pertanyaan saat sesi diskusi setelah penyuluhan dan mengikuti semua gerakan senam yang diajarkan.

Setiap olahraga sebenarnya sama baiknya untuk mengendalikan tekanan darah tinggi, mulai dari olahraga aerobik, kardio, latihan kelenturan, hingga latihan kekuatan. Pada lansia khususnya pada pasien hipertensi cukup melakukan aktivitas fisik intensitas sedang. Pada dasarnya, setiap aktivitas fisik yang meningkatkan detak jantung dan pernapasan dianggap sebagai olahraga untuk hipertensi yang baik (Kusmana, 2002).

\section{Diskusi}

Peserta kegiatan pengabdian yang hadir saat diadakan kegiatan ini meyatakan bahwa sudah bertambahnya pengetahuan tentang penyakit hipertensi yang dideritanya. Perserta kegiatan juga menyatakan mau melakukan senam hipertensi secara rutin dan mengkonsumsi obat herbal sesuai kondisinya di rumah.

Latihan olahraga yang dilakukan agar dapat berpengaruh terhadap efisiensi kerja jantung. Sebaiknya latihan berada pada intensitas sedang yaitu denyut jantung $150170 /$ menit. Intesitas sedang $\leq 70-80 \%$ dari kapasitas senam maksimal. Intesitas 


\section{Jurnal ABDI MERCUSUAR}

latihan adalah lamanya yang dilakukan, khususnya latihan dan intesitas latihan yang paling penting harus dipenuhi. Frekuensi latihannya 3-5 kali seminggu dengan lama latihan 20-60 menit sekali latihan. Latihan olahraga dapat menyebabkan dilatasi pembuluh-pembuluh darah sehingga tekanan darah menurun. Orang yang melakukan latihan 3 kali seminggu akan mengalami peningkatan daya tahan kardiorespirasi dan latihan olahraga secara teratur bisa menurunkan resiko penyakit jantung. Olahraga aerobik terutama bermanfaat untuk meningkatkan dan mempertahankan kesehatan dan daya tahan jantung, paru, peredaran darah, otot-otot, dan sendi-sendi. Senam aerobic low impact mempunyai pengaruh besar terhadap tubuh, khususnya terhadap daya tahan paru dan jantung (Kusmana, 2002).

Penderita hipertensi respon peningkatan tekanan darah mungkin berlebihan setelah selesai aktivitas senam. Kemudian tekanan darah akan berkurang dibawah tekanan darah saat istirahat yang disebut dengan hipotensi pasca-latihan. Penurunan tekanan darah bisa berkurang 10-20 mmHg dan biasanya bertahan setelah latihan. Adapun penelitian yang tidak sejalan dengan penelitian ini adalah penelitian yang dilakukan oleh Bernadus (2015) menunjukan bahwa pelaksanaan senam prolanis terhadap lansia tidak memiliki pengaruh terhadap penurunan tekanan darah sistolik maupun diastolik (Rosdiana et al., 2017).

\section{Kesimpulan dan Saran}

Setelah dilakukan kegiatan pengabdian kepada masyarakat ini dapat dilihat peserta kegiatan dapat memahami penyuluhan tentang hipertensi dan pengobatan herbal hipertensi serta klien juga sudah bisa melakukan gerakan senam hipertensi.

Diharapkan nanti klien dapat mengunakan pengobatan herbal nanti di rumah sesuai dengan kondisinya dan klien juga melakukan senam hipertensi secara teratur sehingga tekanan darah tinggi yang dialaminya dapat terkendali.

\section{Ucapan Terimakasih}

TIM Pengabdian kepada masyarakat mengucapkan terimakasih kepada Pimpinan Klinik MERCUBAKTIJAYA yang telah memberikan izin dan kesempatan kepada TIM untuk melakukan kegiatan pengabdian kepada masyarakat di klinik. Tidak lupa TIM juga mengucapkan kepada Ketua STIKes MERCUBAKTIJAYA Padang yang telah memberikan izin dalam kegiatan ini.

\section{Daftar Referensi}

Amin. (2015). Buku Ajar Keperawatan Hipertensi. Nuha Medika.

Bustan, M. (2015). Manajemen Pengedalian Penyakit Tidak Menular. Rineka Cipta.

Kusmana. (2002). Olahraga Bagi Kesehatan Jantung. Fakultas Kedokteran Universitas Andalas.

Kusniadi, \& Nurahmani. (2014). Stop Diabetes, Hipertensi, Kolesterol Tinggi, Jantung Koroner. Nuha Medika. 


\section{Jurnal ABDI MERCUSUAR}

Vol. 01, No. 02, Desember, 2021, pp. 001- 006

Lumempouw, Wungouw, \& Polii. (2016). Pengaruh senam Prolanis terhadap penyandang hipertensi. Jurnal E-Biomedik,.

Rosdiana, Raharjo, \& Indarjo. (2017). Implementasi Program Pengelolaan Penyakit Kronis (Prolanis). Nuha Medika. 